\title{
Evaluating the Jordanian Experience in the Transition to a Knowledge Economy
}

\author{
Saleh S. Barakat ${ }^{1} \cdot$ Hisham M. AISmadi $^{1} \cdot$ Khalifeh M. Abu-Ashour $^{2}$
}

Received: 8 July 2020 / Accepted: 19 January 2021 / Published online: 2 March 2021

(c) The Author(s) 2021

\begin{abstract}
In 2002, Jordan sought to shift towards a knowledge economy through the adoption of several policies supporting the transition towards a knowledge economy. The current study aims to evaluate the transition process as Jordan moves towards knowledge economy. Majority of the indicators presented in this study showed regression, despite some important steps taken by Jordan. The results showed a noticeable decline in the knowledge economy indicators in Jordan and also that Jordan is going through difficult economic conditions on account of minimal global support. The pace of the transition towards the knowledge economy has been greatly affected by deteriorated economic situations of Jordan. However, Jordan has been able to obtain some positive indicators with respect to human capital and creativity, and these endorse the significance of investing in human capital, reviewing the law and legal system, and education policies in Jordan. These results provide a guideline to Jordanian authorities so that they can take necessary measures to meaningfully invest in knowledge economy.
\end{abstract}

Keywords Experience $\cdot$ Jordan $\cdot$ Knowledge economy $\cdot$ Policies

\section{Introduction}

Major revolutions have occurred in the global economy in the last two decades. In order to improve the economy, focus on key areas is mandatory (Širá et al., 2020). A transition is being observed from agriculture economy, where manual labor is the critical element, to industrial economy, where the management of resources was the essential element. According to Tripathi (2006), these transitions cause the movement of global economy towards the information era whose core elements are the

Khalifeh M. Abu-Ashour

abuashour@yu.edu.jo

1 Al-Balqa Applied University, As-Salt, Jordan

2 Yarmouk University, Irbid, Jordan 
connectivity and software-driven products. The transition is characterized by global competition, frequent changes, rapid information processing, faster communication, enhanced complexity in business, and pervasive globalization. The rapid transformation has changed the dynamics of economy, and new firms have emerged and captured the market economy. As explained by Pasternack and Viscio (1998), the rapidly evolving and growing economy has initiated the transformation process in every sector, for example, changes in the production and perceptions of consumers. The current dynamics of the economy demands an evolved and efficient economic system.

The formation of knowledge economy highlights the onset of a new stage in the development of the global economy (Zhuparova et al., 2018). The modern era came up with the emergence of a unique economic phenomenon, characterized by a significant decrease in the costs of coding, transmitting, and acquiring knowledge. Since the mid-twentieth century, economic literature has on the post-industrial era, where indicators have begun to move towards the adoption of knowledge as a basis to build the economic system of countries. The development of the economic system depends on technological development, rapid exchange, and adoption of knowledge and data, which is known as knowledge society (Hadad, 2017). It includes the indicators of Jordan's spending on scientific research and creativity.

The need of knowledge economy is based on the creation of modern economies, whereas scientific research, knowledge, and innovation lead to economic development and growth (Wirba, 2017). The increased importance of knowledge in all economic sectors has contributed towards the continuous development of knowledge economy (Marti \& do Rosário Cabrita, 2012). This requires strengthening longterm investments in education, developing the ability to innovate, modernizing the information infrastructure, and creating an enabling economic environment (Chen \& Dahlman, 2005). According to Pupavac et al. (2019), the new economy has become focused on developing workforce knowledge so that knowledge increases the contribution of productive institutions to GDP. Kaur and Mehta (2016) emphasized that knowledge-based productive capabilities have greater potential to generate a competitive advantage, and this requires that productive institutions use knowledge at the higher basic level of production to meet global competitiveness.

The focus on transformation to "Knowledge economies" is an effort to diversify the economies and create jobs with high knowledge content among the local populations (Hvidt, 2016). The importance of the knowledge economy lies in the fact that it possesses the ability to innovate, find, and generate entirely new intellectual and knowledgeable outcomes. It helps to create and find unprecedented, more satisfying, and convincing products for the consumers and distributors (Begg, 2003). Therefore, the focus is on developing knowledge economy as a result of increasing importance of knowledge in all sectors of economy (Marti \& do Rosário Cabrita, 2012), and this requires strengthening long-term investments in education, developing the ability to innovate, modernizing the information infrastructure, and creating an enabling economic environment (Chen \& Dahlman, 2005).

Since the twentieth century, which is considered to be an industrial era, the need of a more efficient and effective economic system has been emphasized, an economic system in which primary indicators must be other than labor and capital. It leads to the emergence of a unique economic phenomenon, characterized by a 
significant decrease in the costs of coding, transmitting, and acquiring knowledge; this was reflected in a rapid increase in knowledge outputs, and the growing place of change in economic activity and activities was devoted to innovation. The knowledge economy can be defined as a possible way of transforming society to achieve sustainable economic growth and combat challenges arising from the growing scarcity of resources (Rezny et al., 2019). As explained by Hadad (2017), the economic system of a country is based on knowledge rather than capital and labor. The economy functions on the technological advancements and frequent exchange and adaptation of knowledge and data. The relatively smaller states with limited natural resources can depend on this economy and be better benefited in comparison with the traditional economy system. According to Talal (2019), the Jordanian economy and features show similarities with that of Finland; therefore, Jordan can also perform as well as Finland with respect to knowledge-based economy. Therefore, the current study aims to evaluate the transition process as Jordan moves towards a knowledge economy.

\section{Theoretical Background}

In 1999, the World Bank Institute launched a project called "Knowledge for Development" (K4D). Its goals were to raise awareness of national policymakers to encourage economists to combine global and local knowledge and highlight comparative advantages (World Bank, 2008). Moahi (2007) agreed that the emergence of a knowledge economy depends on the following three reasons:

- The information revolution and the spread of networks where knowledge information has contributed greatly to the productivity of countries. Also, production dependence on knowledge has increased, as more than $70 \%$ workers in advanced economies are information workers.

- Globalization that spread at an unprecedented speed and abolished customs borders and restrictions; it also opened the way to FDI, eliminated restrictions on the regulation of markets in many countries of the world, and minimized monopolies of many sectors such as telecommunications and others.

- Book and specialists that have increased interest in knowledge during the last 20 years; additionally, they included topics of knowledge and human capital and their role in the international competition of many international economic organizations such as the Organization for Economic Cooperation and Development.

The axes of knowledge economy can be developed continuously and adapted to produce knowledge and apply it effectively through education and training. Perhaps it aims to help communication and spread information and data. There is no doubt that technology, information, and communications represent the fundamental structure of the new economy. Their presence in universities, companies, and organizations is important, as they create innovators and then new innovations that constitute an increase in the added value of the output (Sheehan \& Hoy, 2000). 
According to the World Bank, there are several indicators through which one can know the possibility of a country joining within this new economy, which is based on the knowledge revolution. These indicators are presented in Fig. 1.

With regard to the experience of a Jordanian woman, Jordan has sought to move towards a knowledge economy by taking several practical steps represented by the project to develop education towards a knowledge economy ERfKE II since the year 2002. The Jordanian education initiatives were taken to enhance the partnership between the public and private sectors by investing in knowledge. For this purpose, a project named Jordanian Knowledge Stations for the Transformation to the Digital and Knowledge Economy was represented to the Jordanian citizens to use information and communications technology.

The Digital Content Pioneers initiative launched by the Jordanian Association of Information and Communications Technology Companies aims to enhance the reality of Arab content in the field of digital economy. This enhancement depends on developing the capabilities of students to build a generation capable of writing digital content in the Arabic language in line with the information revolution taking place in the world. Despite these efforts and initiatives, whether formal or by the private sector in Jordan, Jordan still occupies low levels of knowledge economy indicators according to the global classification.

\section{Methods}

The data for this study was collected through local and international statistical bulletins and also from the International Telecommunication Union, the World Bank (World Bank Development), and the United Nations. The main aim of this study was to achieve a true picture of the current indicators of the Jordanian technological sector and global innovation. Data of several years was chosen and evaluated to know the reality of Jordan's investment in technology, and its implications for the Jordanian economy.
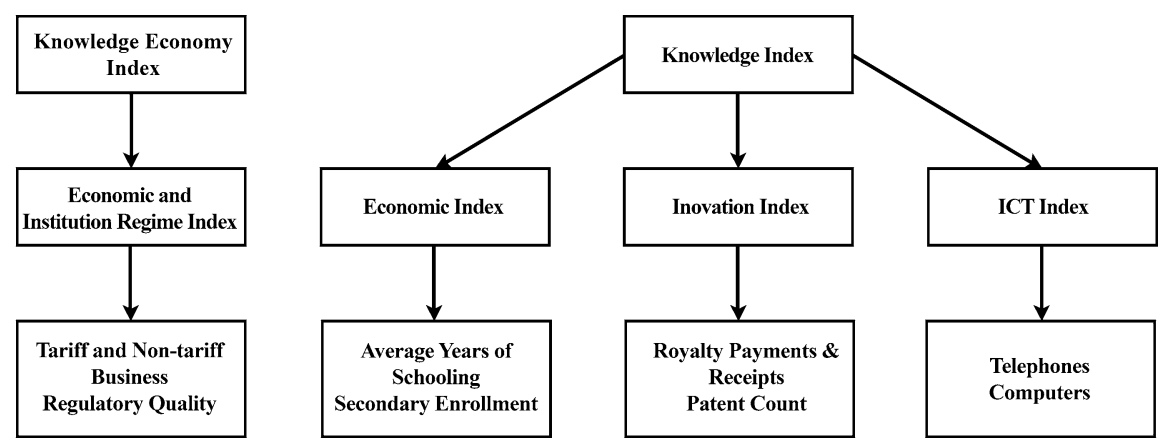

Fig. 1 Knowledge indexes (source: World Bank) 
Table 1 Indicators of Jordan's spending on scientific research and creativity

\begin{tabular}{llll}
\hline Scientific research and creativity & Currently & 2012 & 2017 \\
\hline $\begin{array}{l}\text { Expenditure on scientific research as a percentage of GDP } \\
\begin{array}{l}\text { Number of internationally published scientific papers (as reported in } \\
\text { the Thomson ISI index }\end{array}\end{array}$ & $0.34 \%$ & $0.10 \%$ & $1.5 \%$ \\
$\begin{array}{l}\text { The number of applications submitted by Jordanians to register a } \\
\text { patent from the year 2000 }\end{array}$ & 246 & 100 & 2500 \\
$\begin{array}{l}\text { The number of book manuscripts that have received deposit numbers } \\
\text { from the National Library Department since 1994 }\end{array}$ & 22,550 & 42,000 & 5000 \\
\hline
\end{tabular}

\section{Results}

The results shown in Table 1 indicate that there is development in the Jordanian environment at the level of spending indicators for scientific research and creativity. This means that Jordan has made a tangible improvement and progress in this direction and that spending until 2017 was below the required level, as the amount of spending on scientific research reached $1.5 \%$ of the local Jordanian product. Figures 2 and 3 show the expenditure on scientific research as a percentage of GDP from year 2012 to 2017.

The decline in Jordan with respect to all indicators of the technology axis, with the exception of the technological environment index, is presented in Table 2 and Fig. 3.

Table 3 presents the Jordan's rank in online use hub for the years 2014-2017 and shows that Jordan has retracted all axes related to electronic usage (Fig. 4).

Table 4 clearly shows that Jordan has retreated in all axes of the economic impact. Moreover, Fig. 5 illustrates Jordan's ranking in the sub-axes of the economic impact axis for the years 2014-2015 and 2015-2016.

It appears from Table 5 that Jordan is still unstable in terms of indicators of global innovation in 2016 and 2017, which means that the experience of the shift towards a knowledge economy is still weak. Figure 6 shows the individual index input innovation for Jordan.

\section{Expenditure on scientific research as a percentage of GDP}

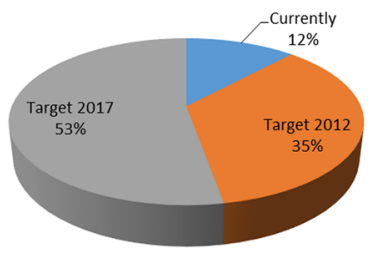

Expenditure on scientific research as a percentage of GDP

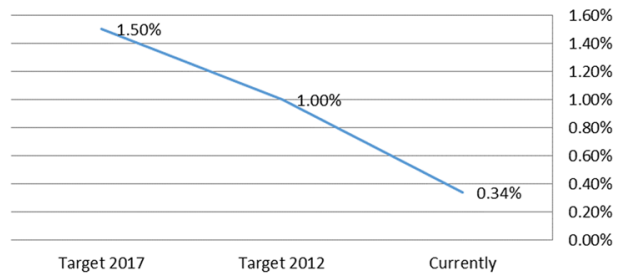

Fig. 2 Expenditure on scientific research as a percentage of GDP from years 2012 to 2017 


\title{
Ranking among the 143 participating countries
}

\author{
2015 - $2016 \square 2014-2015$
}

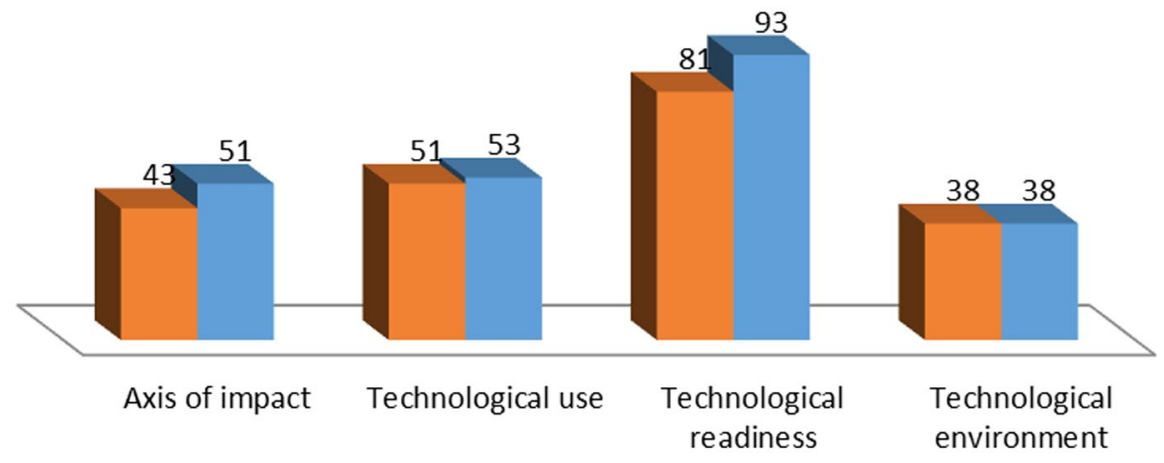

Fig. 3 Jordan's ranking in four main axes between 2014 and 2015, and 2015 and 2016

\section{Discussion}

The statistical analysis conducted in this study clearly elaborates the regression in the adaptation of a knowledge-based economy system in Jordan. The data represented in Table 1 elaborates the expenditure pattern of Jordanian GDP on the scientific knowledge and research development. According to Jaruzelski et al. (2005), sustained and developed scientific knowledge and research department is necessary for the transition towards a knowledge-based economic system. In the case of Jordan, there are major spending shifts. The spending on the research has not been constant in the past 3 years, which disrupted the pattern and growth in the research department. As elaborated in Fig. 2, the expenditure shows a decline, reducing the subsidy and responsibilities from the government's perspective.

The statistics of Table 2 illustrates that the global ranking of Jordan in the technological environment was constant from the years 2014 to 2016. There was

Table 2 Jordan ranked in the four main axes for 2 years 2014-2015 and 2015-2016

\begin{tabular}{llll}
\hline The main hub & $\begin{array}{l}\text { Ranking among the 143 } \\
\text { participating countries for } \\
\text { the two years 2015-2014 }\end{array}$ & $\begin{array}{l}\text { Ranking among the 139 } \\
\text { participating countries for } \\
\text { the year 2016-2015 }\end{array}$ & Level of change \\
\hline Technological environment & 38 & 38 & - \\
Technological readiness & 93 & 81 & Retreat \\
Technological use & 53 & 51 & Retreat \\
Axis of impact & 38 & 43 & Retreat \\
\hline
\end{tabular}


Table 3 Jordan's rank in the hubs for the online use hub for the years 2014-2017

\begin{tabular}{llll}
\hline The main hub & $\begin{array}{l}\text { Ranking among the 143 } \\
\text { participating countries } \\
\text { for the years 2014-2015 }\end{array}$ & $\begin{array}{l}\text { Ranking among the 139 } \\
\text { participating countries } \\
\text { from 2015-2016 }\end{array}$ & Level of change \\
\hline Technological use & 51 & 53 & Retreat \\
Use of electronic individuals & 69 & 70 & Retreat \\
E-business use & 50 & 41 & Retreat \\
Use of e-government & 69 & 47 & Retreat \\
\hline
\end{tabular}

not a significant positive change in the technological advancement in the country. As mentioned in Fig. 3, the technological preparedness level of the country drops from 93rd position to 81st position. The technological use upgraded from 53rd to 51 st position, and the axis of impact was shifted from 38 th to 43 rd position. The overall performance of the country was on the borderline. The growth of technology in the country is steady, whereas in comparison with the GDP expenditure on the development of these departments, the growth was negligible.

The usage of E-government and E-business has shown a remarkable and significant transition since 2014. As shown in Table 3, the country shows a rapid growth in both the technological sectors. All the axes of technological usage in the country are enhanced. As explained by Khanmirzaee et al. (2018), the roles of technological advancement and consumption by the population are the most essential element contributing towards the growth of a knowledge-based economy system. However, the increase usage is not the assurance of sustainability of a

\section{Ranking among the 143 participating countries}

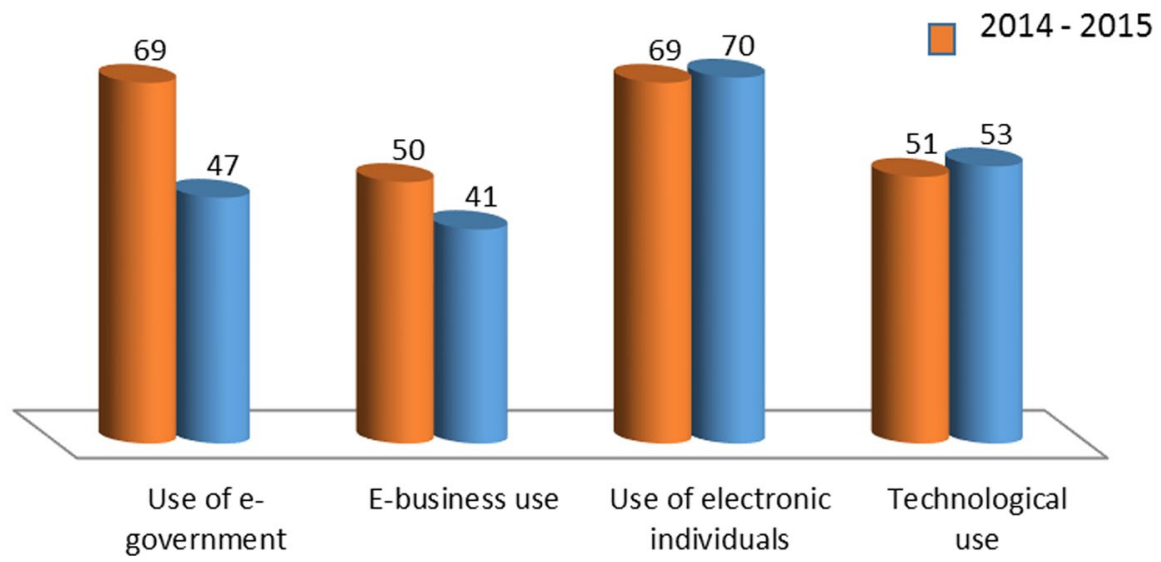

Fig. 4 Jordan's ranking in the hubs between 2014 and 2017 
Table 4 Jordan's ranking in the sub-axes of the economic impact axis for the years 2014-2015 and 2015-2016

The main hub

$\begin{array}{lll}\begin{array}{l}\text { Ranking among the } \\ 143 \text { participating }\end{array} & \begin{array}{l}\text { Ranking among } \\ \text { the } 139 \text { participat- }\end{array} & \begin{array}{l}\text { Level of } \\ \text { change }\end{array} \\ \text { countries for the } & \text { ing countries from } & \\ \text { years 2014-2015 } & 2015 \text { to 2016 }\end{array}$

Economic impact

42

61

Retreat

The impact of the communications and informa- 41

50

Retreat

tion technology sector on new services and products

Patent applications for telecommunications and information technology with the Interna-

Retreat

tional Organization for International Property (WIPO)

The impact of communications and information technology on new organizational models

Jobs that require a high amount of knowledge

31

56

Retreat

49

$\mathrm{n} / \mathrm{a}$

Retreat

knowledge-based economy. It is possible that the main increase in consumption is in the form of globalization and is mainly for entertainment purposes. The variability of enhanced consumption is not the assurance of a sustained economy;

\section{Ranking among the 143 participating countries}

$2015-2016$
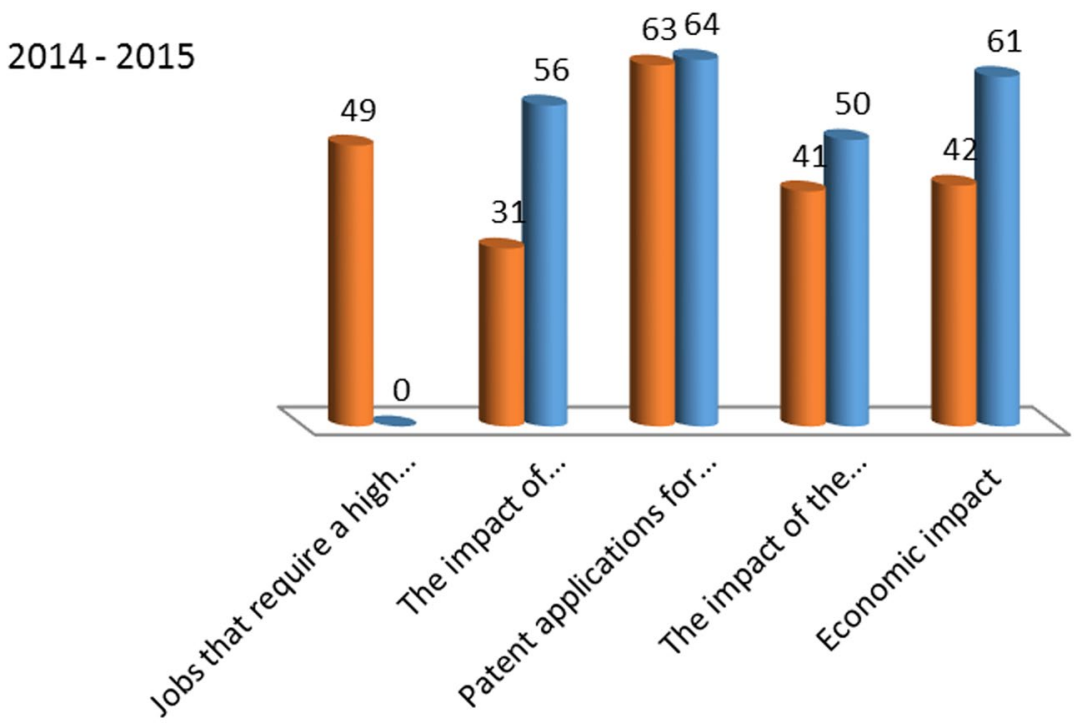

Fig. 5 Jordan's ranking in the sub-axes for the years 2014-2015 and 2015-2016 
Table 5 Jordan's performance in the Global Innovation Index (GII) for the year 2017

\begin{tabular}{lllll}
\hline Rank & 2016 & 2017 & Type of change & $\begin{array}{l}\text { The value } \\
\text { of the } \\
\text { change }\end{array}$ \\
\hline $\begin{array}{l}\text { Individual index input innovation } \\
\quad \text { Institutions }\end{array}$ & 63 & 64 & Negative & -1 \\
$\quad$ Research and human capital & 86 & 83 & Positive & 3 \\
$\quad$ Infrastructure & 79 & 87 & Negative & -8 \\
Market development & 115 & 116 & Negative & -1 \\
$\quad$ Business development & 116 & 104 & Positive & 12 \\
Individual index innovation outputs & & & & 0 \\
$\quad$ Knowledge and technology output & 79 & 79 & - & 6 \\
Creativity outputs & 78 & 72 & Positive & \\
\hline
\end{tabular}

however, it is still a positive sign of increase in the knowledge of the population regarding internet which will be beneficial in future.

As shown from Fig. 5, Jordan has retreated its level with respect to 143 other participating countries. Previously, the country was ranked 42 in economic impact, which has now lowered to 61 st position. The role of communication and information technology has also created an impact in the shift of the country's ranking from 41st to 50th. The new organization models have greatly been influenced by the technological advancements, as their level shows transition from 31st to 56th. According to Hadad (2017), the technological advancement and its impact on the new organizations is a positive mark of knowledge-based economic growth.

Jordan's performance on the global innovative index is mentioned in Table 5 which clearly illustrates that the institution growth of the country, which is an essential element of a country's knowledge-based economic growth, is negative in the case of Jordan. The negativity in growth will create a decline in sustainability of a knowledge-based economy (Hadad, 2017). According to Popescu et al. (2016), research and human capital are the significant components in development of a knowledge economy. The variables of Jordan show a positive growth in the last years. The growth rate is steady, but it is growing eventually in comparison with other factors. As explained in the study of Nurunnabi (2017), the growth in
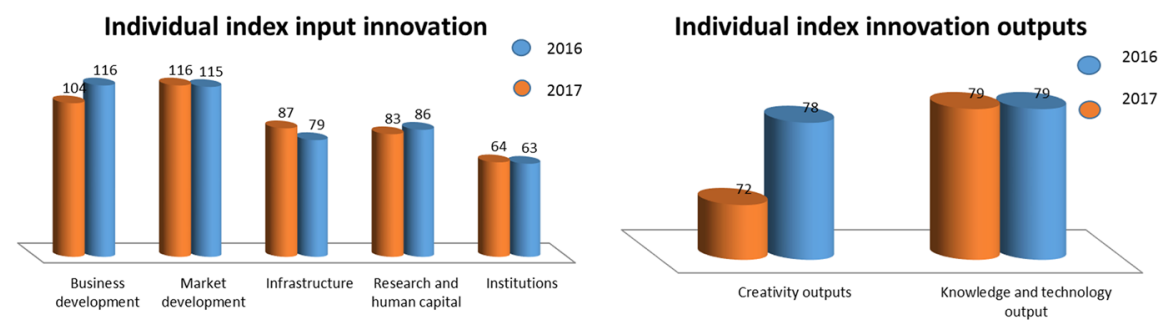

Fig. 6 Individual index input innovation for Jordan 
infrastructure and market development are the suitable elements to mark the performance of a knowledge-based economy in any country. The elements of infrastructure development and market growth are significantly declining in Jordan. These factors assure that the knowledge-based economic growth in Jordan is in regression, despite of all the efforts put in by the government along with the GDP expenditure on the development of the desired sectors. The economy shows a decline in growth due to the lack of education and understanding of technological advancements.

\section{Conclusion}

The study results showed that Jordan has experienced a noticeable decline on the knowledge economy indicators. Perhaps, Jordan is going through difficult economic conditions in terms of receiving refugees and the low level of global support. The economic situation of Jordan has negatively affected the process of the transition towards a knowledge economy. On the other hand, Jordan has achieved some positive indicators on the level of research, human capital, and creativity outcomes. These results confirm the importance of reviewing many of the rules and policies related to investing in human capital and reviewing the law and legal system, and education policies in Jordan. It has been shown that educational reforms in Jordan are informed by problematic cultural assertions, resulting in overlooking of schools that may serve as sites to question "global" norms and development goals by students as well as teachers. Important insights are offered by perspectives of Jordanian educators for building the knowledge economy. There is a need to highlight needs of the economy and education sector that is currently characterized by secondary education in Jordan. The perspectives of Jordanian educators shared here offer important insights as to how economiv educational policies should build the knowledge economy plays out in practice. They also highlight how the officially stated needs of the economy and education sector may be discouraged by the challenges that currently characterize secondary education in Jordan. However, future studies need to highlight the importance of focusing on productive knowledge, adopting creative initiatives, providing greater government support for technology infrastructure, and integrating technology in education to develop qualified forces to enhance Jordan's place in the international indicators of the knowledge economy.

Acknowledgements The authors are very thankful to all the associated personnel in any reference that contributed in/for the purpose of this research.

Data Availability The data will be available for review from the corresponding author on request.

\section{Declarations}

Conflict of Interest The authors declare that they have no conflict of interest. 
Open Access This article is licensed under a Creative Commons Attribution 4.0 International License, which permits use, sharing, adaptation, distribution and reproduction in any medium or format, as long as you give appropriate credit to the original author(s) and the source, provide a link to the Creative Commons licence, and indicate if changes were made. The images or other third party material in this article are included in the article's Creative Commons licence, unless indicated otherwise in a credit line to the material. If material is not included in the article's Creative Commons licence and your intended use is not permitted by statutory regulation or exceeds the permitted use, you will need to obtain permission directly from the copyright holder. To view a copy of this licence, visit http://creativecommons.org/ licenses/by/4.0/.

\section{References}

Begg, D. (2003). Economies. London: The McGrew-Hill Companies.

Chen, D. H., \& Dahlman, C. J. (2005). The knowledge economy, the KAM methodology and World Bank operations. World Bank Institute Working Paper, (37256).

Hadad, S. (2017). Knowledge economy: Characteristics and dimensions. Management dynamics in the Knowledge economy, 5(2), 203-225. https://doi.org/10.25019/mdke/5.2.03

Hvidt, M. (2016). Challenges to implementing 'Knowledge based economies' in the Gulf region. Videnscenter om det moderne Mellemøsten.

Jaruzelski, B., Dehoff, K., \& Bordia, R. (2005). strategy+business. Retrieved from: https://www.ipeg.com/_ UPLOAD\%20BLOG/2006\%20Booz\%20Allen\%20Global\%20Innovation\%201000\%20Preprint.pdf

Kaur, V., \& Mehta, V. (2016). Knowledge-based dynamic capabilities: A new perspective for achieving global competitiveness in IT sector. Pacific Business Review International, 1(3), 145-208. https:// doi.org/10.1007/978-3-030-21649-8_5

Khanmirzaee, S., Jafari, M., \& Akhavan, P. (2018). A study on the role of science and technology parks in development of knowledge-based economy. World Journal of Entrepreneurship, Management and Sustainable Development.

Marti, J. M. V., \& do Rosário Cabrita, M. (2012). Entrepreneurial excellence in the knowledge economy: Intellectual capital benchmarking systems. Palgrave Macmillan.

Moahi, K. H. (2007). Globalization, knowledge economy and the implications for indigenous knowledge. International Review of Information Ethics, 7, 55-62.

Nurunnabi, M. (2017). Transformation from an oil-based economy to a knowledge-based economy in Saudi Arabia: The direction of Saudi vision 2030. Journal of Knowledge Economy, 8(2), 536-564.

Pasternack, B. A., \& Viscio, A. J. (1998). The centerless corporation: A model for tomorrow: Build organizations around people, knowledge, values and coherence, not just operations. Strategy and Business, 10-21.

Popescu, G. H., Comanescu, M., \& Sabie, O. M. (2016). The role of human capital in the knowledgenetworked economy. Psychosociological Issues in Human Resource Management, 4(1), 168.

Pupavac, D., Budić, H., \& Marinac, A. (2019). Achieving dynamic stability of organization in knowledge economy. Journal Sustainable Development, 9(23), 57-71.

Rezny, L., White, J. B., \& Maresova, P. (2019). The knowledge economy: Key to sustainable development? Structural Change and Economic Dynamics, 51, 291-300. https://doi.org/10.1016/j.strueco.2019.02.003

Sheehan, K. B., \& Hoy, M. G. (2000). Dimensions of privacy concern among online consumers. Journal of Public Policy and Marketing, 19(1), 62-73. https://doi.org/10.1509/jppm.19.1.62.16949

Širá, E., Vavrek, R., Kravčáková Vozárová, I., \& Kotulič, R. (2020). Knowledge economy indicators and their impact on the sustainable competitiveness of the EU countries. Sustainability, 12(10), 4172. https://doi.org/10.3390/su1210417

Talal, A. (2019). What is the state of the knowledge economy in Jordan? Retrieved From: https://www. jordantimes.com/opinion/talal-abu-ghazaleh/what-state-knowledge-economy-jordan

Tripathi, M. (2006). Transforming India into a knowledge economy through information communication technologies-Current developments. The International Information and Library Review, 38(3), 139-146. https://doi.org/10.1016/j.iilr.2006.06.007

Wirba, A. V. (2017). The role of research in knowledge economy within GCC countries. European Journal of Business and Management, 9(3), 166-184.

World Bank. (2008). Knowledge Economy index (KEI) 2012. Retrieved from: www.world.org/Kam 
Zhuparova, A., Sagiyeva, R., \& Kalmakova, D. (2018). The development knowledge-based economy: A literature review. Challenging the Status Quo in Management and Economics, 555.

Publisher's Note Springer Nature remains neutral with regard to jurisdictional claims in published maps and institutional affiliations. 